\title{
POVEZANOST SPECIFIČNE KOORDINACIJE MLADIH ODBOJKAŠICA I NIVOA IZVOĐENJA ELEMENATA TEHNIKE U ODBOJCI
}

\author{
Tamara Karalić1, Adriana Ljubojević1 ${ }^{1}$, Nikolina Gerdijan ${ }^{1}$ i Željko Vukić1 \\ ${ }^{1}$ Fakultet fizičkog vaspitanja i sporta Univerzitet u Banjoj Luci, Bosna i Hercegovina
}

Originalni naučni članak

\section{SAŽETAK}

U istraživanju transverzalnog karaktera učestvovalo je 40 odbojkašica odabranih prema jasno definisanim kriterijumima. Primijenjeni su testovi iz domena specifične odbojkaške koordinacije (prediktori) i preciznosti odigravanja lopte podlakticama (kriterijumi). Cilj je ispitati povezanost prediktorskih sa kriterijumskim varijablama i na taj način stvoriti uslov za predviđanje nivoa preciznosti odbojkašica kod izvođenja zadane tehnike. Odbojkašice su pokazale da su njihove koordinativne sposobnosti pri izvođenju zadatka pogađanje horizontalnog cilja „,̌ekićem“ (ČEHOR) statistički značajne. U testu pogađanje vertikalnog cilja „,̌ekićem“ (ČEVER) kao značajne pokazale su se dvije vrste koordinacije, koordinacija u prostoru $i$ koordinacija na mreži, dok su se u trećem testu pogađanje horizontalnog cilja „,̌ekićem“ u poziciji 2 (ČEPOZ2), kao značajne pokazale koordinacija na mreži i jednoručno žongliranje loptom kroz obruč. Značaj i složenost koordinacije u ovom $i$ sličnim transverzalim istraživanjima je evidentan, te je zaključak da povezanost specifičnih koordinativnih sposobnosti sa preciznim izvođenjem odbojkaške tehnike, postoji $i$ da latentni faktori, koji su odredili koordinacione sposobnosti odbojkašica, mogu djelovati $i$ samostalno, ali i zavisiti jedan od drugog. Nesumnjivo, bez dobro koordinisanog odbojkaša/ice, se ne može očekivati efikasno izvođenje zadanih tehničko-taktičkih struktura u odbojci.

Ključne riječi: odbojka, koordinacija, preciznost. 


\section{UVOD}

Odbojka je sportska aktivnost koja obiluje različitim kretnjama igrača. Jasno je da je za izvođenje tako zahtjevnih kretanja, učenje novih pokreta, te brzu izmjenu jednog kretanja s drugim (Drabik, 1996), koordinacija, nezaobilazan faktor uspjeha odbojkaša. Za koordinaciju se kaže da je oblik motoričke inteligencije jer tokom igre učestvuje, manje-više, u svim kretnim oblicima i aktivnostima (anticipiranje putanje lopte, vremensko usklađivanje (timing) kretanja do lopte, opažanje kretanja saigrača i protivnika, veliki vremenski pritisak u periodu tranzicije obrane i napada, osjećaj za loptu kod prijema servisa, blokiranje lopte, te precizno dodavanje, smečiranje ili serviranje lopte). Njena multidimenzionalnost i složenost nedvojbeno zahtijeva jasno definisanje faktora, latentnog karaktera, koji mogu biti čak i univerzalni za ovu motoričku sposobnost. Kompleksnost ove motoričke sposobnosti je davno utvrđena. Dosadašnja istraživanja (Verstegen i Marcello, 2001; Stein, Simonidis, Seemann i Schwameder, 2010; Idrizović, 2011; Karamatić, Vuljanić i Peršun, 2011; Macner, 2011; Njaradi, 2011; Tomljanović, Krespi i Bešlija, 2011; Vučetić, Sukreški i Zuber, 2011; Urgesi, Savonitto, Fabbro i Aglioti, 2012; Milanović, Šalaj i Gregov, 2012; Yasumitsu i Nogawa, 2013; Button, Wheat i Lamb, 2014; Pion, Fransen, Deprez, Segers, Vaeyen, Philippaerts i Lenoir, 2015; Šimonek, 1998; 2006; 2009; 2014; 2016) uglavnom potvrđuju pretpostavku da koordinacija, između ostalog, podrazumijeva preciznost izvođenja zadatka, ritmičnost (izvođenje kretnih radnji tačno i u određenim prostornim i vremenskim razmacima), ravnotežu (sposobnost održavanja stabilnog položaja u dinamičkim strukturama kretanja) sposobnosti reakcije, sposobnosti kinestetičke diferencijacije (korištenje odgovarajuće količine snage za određeni pokret), orjentaciju u prostoru (sposobnost prilagođavanja vlastitog tijela ili dijela tijela u prostoru), ekonomičnost kretanja, kao i sinhronizaciju pokreta u vremenu. Dakle, zbog velikog broja raznovrsnih, tehnički zahtjevnih, komplikovanih i netipičnih pokreta, u odbojci se s pravom može govoriti o dva ključna faktora za uspješnost: specifičnoj koordinaciji povezanoj sa vještinom rukovanja loptom i specijalnoj, odbojkaškoj preciznosti.

U namjeri da se ispita povezanost prediktorskih varijabli specifičnih koordinacionih sposobnosti odbojkašica sa nivoom odigravanja/dodavanja lopte podlakticama ${ }^{1}$, kao sistema kriterijumskih varijabli, provelo se istraživanje transverzalnog karaktera. Osnovna pretpostavka

\footnotetext{
${ }^{1} \mathrm{U}$ daljem tekstu koristi se termin "čekić".
} 
bila je da će, na osnovu rezultata testova iz prostora specifičnih koordinativnih sposobnosti i rezultata testova tehnike odigravanja/dodavanje lopte "čekićem", biti moguće predvidjeti nivo preciznosti odbojkašica. Dakle, radilo se o opštoj, specifičnoj ili situacionoj koordinaciji, u istraživanju je došla do izražaja suština ove sposobnosti: pravilan odnos utvrđenih latentnih faktora kao dijelova cjeline, koji daju efektivne rezultate.

\section{METODE}

U realizaciji testova učestvovalo je 40 odbojkašica. Kriterijumi za izbor ispitanica su: (1) starost ispitanica u uzorku je od 14 do 16 godina ( \pm 6 mjeseci); (2) da su aktivne članice odbojkaških klubova iz Republike Srpske; (3) da aktivno treniraju odbojku najmanje 2 do 4 godine; (4) da aktivno učestvuju u realizaciji treninga; (5) da je za sve ispitanice planom predviđeno opterećenje od 5 treninga sedmično sa ukupnim trajanjem 1 treninga 90-120 minuta; (6) da su sve ispitanice obavile ljekarski pregled i da su zdrave. Prije početka mjerenja, provjerena je tačnost instrumenta, po potrebi i podešena. Prema postavljenim zadacima istraživanja obezbijeđeni su tehnički uslovi za precizne i tačne rezultate: (1) mjerenje je obavljeno u toku prijepodneva (od 8 do 14 časova); (2) instrumenti su standardne izrade $\mathrm{i}$ kontrolisani su svakodnevno prije početka i u toku mjerenja nakon 10 izmjerenih ispitanika; (3) ispitanici su testirani u sportskoj sali koja je dovoljno prostrana i osvijetljena, a temperatura vazduha takva da su se ispitanice osjećale prijatno (prema pravilima od $16^{\circ}$ do $25^{\circ}$ ); (4) sva mjerenja obavila su dva ili tri mjerioca, s tim što je svaki od njih izvršavao uvijek ista mjerenja; (5) ispitanice koje se mjere su bile propisanoj u sportskoj opremi i (6) rezultati mjerenja čitali su se dok je instrument na mjerenom parametru ispitanika, a osoba koja je evidentirala podatke radi kontrole, glasno ponavljala rezultate prije upisa u karton ispitanika. Testovi su selektovani iz ranije provedenim istraživanjima (Strahonja, Janković i Šnajder, 1982; Strahonja i Janković, 1988; Marelić, Đurković i Rešetar, 2007; Karalić, 2010; Stojanović, N., Stojanović, T., Stojanović, D., Herodek i Jurko, 2014).

Primijenjeni su sljedeći testovi specifične koordinacione sposobnosti za nezavisne varijable:

\section{Koordinacija ruku - Jednoručno žongliranje loptom kroz obruč (ŽONG)}

Cilj: mjeri spretnost pogađanja cilja. Zadatak: odbojkaš stoji u odbojkaškom stavu ispod cilja. Podbacuje loptu jednom rukom udara je pesnicom (ili zategnutim dlanom) i nastoji da pogodi okvir obruča. Kad lopta pređe kroz obruč ili oko obruča nastoji da drugom 
rukom pogodi okvir. Vrijeme izvođenja testa je 20 sekundi. Ako ispitaniku lopta ispadne, uzima drugu loptu i nastavlja zadatak. Konačna ocjena: sabira se ukupan broj pogodaka.

\section{Koordinacija cijelog tijela - Test koordinacije uz mrežu (KOOMRE)}

Cilj: mjeri koordinacionu sposobnost odbojkaša. Zadatak: odbojkaš stoji u odbojkaškom stavu ispred mreže. Skoči i podigne ruke za blok (u skoku šake podigne iznad gornje ivice mreže), doskoči i načini kolut nazad, na liniji napada legne na stomak, jednom se za $360^{\circ}$ tehnikom valjanja okrene ponovo na stomak, nakon toga se okrene prema mreži i skoči za smeč tako da šakom pogodi loptu koju pomoćnik drži iznad mreže. Štoperica se isključuje kad odbojkaš udari po lopti koju pomoćnik drži na dlanu iznad mreže. Konačna ocjena: na postignuto vrijeme dodaje se po jedna sekunda za učinjenu grešku (dodir mreže u bloku, smeču, nespretno kolutanje i valjanje).

\section{Koordinacija nogu - Test koordinacije u prostoru (KOOPRO)}

Cilj: mjeri koordinacionu sposobnost odbojkaša. Zadatak: odbojkaš stoji u odbojkaškom stavu ispred lijeve linije kvadrata. Skoči 3 puta po toj liniji da dođe do sljedeće linije sa tri skoka desnom i lijevom pretči tu liniju tako da se desnom nogom odražava sa desne, a lijevom sa lijeve strane linije i dolaskom na kraj okrenut leđima sa 6 poskoka unazad dođe do četvrte linije, a zatim sa 3 ukrštena koraka pređe preko četvrte linije. Konačna ocjena: na postignuto vrijeme dodaje se po jedna sekunda za učinjenu grešku: veći ili manji broj skokova, grubo narušavanje pravca u odnosu na linije.

\section{Koordinacija nogu - Heksagon test (HEKSA)}

Cilj: mjeri koordinacionu sposobnost i agilnost. Zadatak: odbojkaš stoji u odbojkaškom stavu na sredini heksagona. Odbojkaš je licem okrenut prema liniji A tokom preskakanja svih linija. Skok se izvede preko B, a zatim vrati u sredinu. Tako se preskoče sve linije redosljedom B, C, D, E, F, A. Odbojkaš mora da načini tri kruga, pa da se štoperica zaustavi. Konačna ocjena: uzima se bolje vrijeme od tri pokušaja.

Za procjenu preciznosti odigravanja/dodavanja lopte "čekićem" korištene su sljedeće zavisne varijable:

\section{Pogađanje horizontalnog cilja ,čekićem“ (ČEHOR)}

Cilj: mjeri preciznost pogađanja cilja "čekićem" u horizontalni cilj. Zadatak: odbojkaš stoji u odbojkaškom stavu upravno u odnosu na cilj na udaljenosti od $3 \mathrm{~m}$, uzima lopte podbacuje ih i "čekićem" nastoji da pogodi sredinu obruča. Konačna ocjena: sabira se ukupan broj bodova od 10 pokušaja.

\section{Pogađanje horizontalnog cilja ,čekićem“ u poziciji 2 (ČEPOZ2)}

Cilj: mjeri preciznost pogađanja cilja "čekićem" u horizontalni cilj u poziciji 2. Zadatak: odbojkaš stoji u odbojkaškom stavu u poziciji 6, 1 m iza linije napada. Horizontalni cilj je postavljen u sredini pozicije 2 (1.5 m od mreže i desne bočne linije). Dodavač je u sredini 
pozicije 1 ( $3 \mathrm{~m}$ iza linije napada i desne bočne linije). Dodavač baca lopte u pravcu primača koji pokušava da "čekićem" pogodi cilj u poziciju 2. Konačna ocjena: sabira se ukupan broj bodova od 10 pokušaja.

\section{Pogađanje vertikalnog cilja ,čekićem“ (ČEVER)}

Cilj: mjeri preciznost pogađanja cilja "čekićem" u vertikalni cilj. Zadatak: odbojkaš stoji u odbojkaškom stavu upravno u odnosu na cilj na udaljenosti od $3 \mathrm{~m}$, uzima lopte podbacuje ih i čekićem nastoji da pogodi sredinu odbruča. Konačna ocjena: sabira se ukupan broj bodova od 10 pokušaja.

U svrhu utvrđivanja prirode veze i predikcije efkasnosti pogađanja horizontalnog i vertikalnog cilja "čekićem" na osnovu indikatora specifične koordinacije u odbojci, primijenjena je višestruka (multipla) linearna regresiona analiza. Iz domena diskriminativne analize, a ciljem provjere nivoa povezanosti (jednog ili više) faktora na varijabilitet određene pojave primijenjena je analiza varijanse - ANOVA.

\section{REZULTATI}

U tabeli 1. prikazana je deskriptivna statistika za skup zavisnih i nezavisnih varijabli. Prema prikazanim vrijednostima parametara, distribucija rezultata za cijeli uzorak odbojkašica $(\mathrm{N}=40)$ je uglavnom u granicama normalnosti što ukazuje na homogenost uzorka ispitanika, čime je obezbijeđena dalja obrada podataka.

Tabela 1.Osnovni statistički parametri za skup zavisnih i nezavisnih varijabli

\begin{tabular}{ccccccc}
\hline \multicolumn{7}{c}{ Osnovni statistički parametri } \\
\hline & $\mathbf{N}$ & Mean & Min. & Max. & Std.Dev. & KS \\
ČEHOR & 40 & 6.85 & 5.00 & 9.00 & 1.10 & 0.18 \\
ČEVER & 40 & 8.28 & 6.00 & 11.00 & 1.18 & 0.21 \\
\hline ČEPOZ2 & 40 & 7.00 & 5.00 & 10.00 & 1.30 & 0.42 \\
ŽONG & 40 & 9.73 & 7.00 & 15.00 & 1.99 & 0.47 \\
\hline KOOMRE & 40 & 7.57 & 6.27 & 8.66 & 0.55 & 0.94 \\
KOOPRO & 40 & 9.54 & 8.92 & 10.70 & 0.42 & 0.52 \\
\hline HEKSA & 40 & 25.18 & 24.12 & 26.71 & 0.51 & 0.55 \\
\hline
\end{tabular}

U tabeli 2. vrijednost koeficijenta multiple korelacije između zavisne varijable Pogađanje horizontalnog cilja "čekićem" (ČEHOR) i sistema varijabli specifičnih koordinativnih 
sposobnosti je $\mathbf{R}=\mathbf{0 . 4 6}$ što ukazuje na značajnu povezanosti posmatranih sistema. Povezanost je i statistički značajna na nivou $\mathbf{p}=\mathbf{0 . 0 0 1}$ (Tabela $2 \mathrm{a}$ ). Rezultati su dobijeni na osnovu vrijednosti stepena slobode $\mathbf{d f}_{\mathbf{1}}=\mathbf{2}$ i $\mathbf{d f}_{\mathbf{2}}=\mathbf{3 7}$ i granične vrijednosti F-testa. Za statistički značajne vrijednosti prihvaćene su one čija je (granična) vrijednost F-testa veća ili jednaka od $\mathbf{3 . 2 3}$ na nivou značajnosti od $\mathbf{p}=\mathbf{0 . 0 5}$.

Dobijena vrijednost $\mathbf{R}^{\mathbf{2}}=\mathbf{0 . 1 9 2 9}$ upućuje na zaključak da je $19.29 \%$ ukupnog varijabiliteta

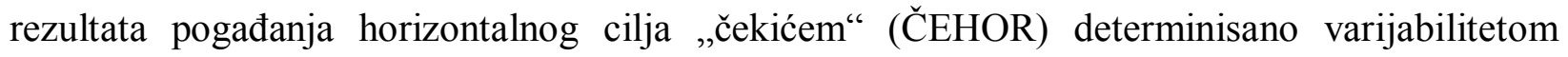
sistema nezavisnih varijabli. Ostatak od $80.71 \%$ nije objašnjen regresionim modelom, dakle, pod uticajem je nekih drugih neidentifikovanih (latentnih) faktora pretpostavlja se fiziološke, antropomotoričke ili psihološke prirode.

Tabela 2. Rezultati multiple regresione analize za zavisnu varijablu Pogađanje horizontalnog cilja „čekićem“ (ČEHOR)

\begin{tabular}{ccccc}
\hline Model & Multiple R & Multiple R $^{\mathbf{2}}$ & Adjusted R $^{\mathbf{2}}$ & Std.Err. of Estimate \\
\hline $\mathbf{1}$ & 0.460032 & 0.192915 & 0.129933 & 10.89724 \\
\hline
\end{tabular}

Legenda: Multiple R - koeficijent multiple korelacije; Multiple $R^{2}$ - koeficijent determinacije; Adjusted $R^{2}$ korigivani koeficijent determinacije; Std.Err. of Estimate - standardna greška ocjene parametara regresije.

Tabela 2a. Rezultati analize varijanse za zavisnu varijablu Pogađanje horizontalnog cilja „с̌ekićem“(ČEHOR)

\begin{tabular}{ccccccc}
\hline $\begin{array}{c}\text { ANOVA } \\
\text { (Effect) }\end{array}$ & SS & df & MS & F & Sig. \\
\hline \multirow{3}{*}{ ČEHOR } & Regresson & 553.78 & 2 & 138.44 & 5.587 & $\mathbf{0 . 0 0 1}$ \\
& Residual & 1239.06 & 37 & 24.78 & & \\
& Total & 1792.84 & 39 & & \\
\hline
\end{tabular}

$d f 1=2 ; d f 2=37 ; f=3.23 ; p=0.05$

Legenda: SS - Suma kvadrata; MS - vrijednosti regresione i rezidualne varijanse; $d f$ - stepeni slobode; $F$ - F test; Sig. - realizovani nivo značajnosti;

Iz skupa varijabli specifinih koordinativnih sposobnosti (Tabela 2b.) pokazalo se da se rezultati testa Pogađanje horizontalnog cilja, „čekićem“ (ČEHOR), koji je korišten za procjenu preciznosti, mogu statistički značajno predvidjeti $(\mathbf{p = 0 . 0 4 2 )}$ na osnovu rezultata testa Koordinacija u prostoru (KOOPRO), koji se koristio za procjenu koordinacije, a čiji beta koeficijent iznosi Beta= -0.199. Ostale varijable specifičnog koordinativnog prostora nemaju statističku značajnost. 
Tabela 2b. Beta koeficijenti - relativni uticaj ili važnost svake nezavisne promjenljive

\begin{tabular}{ccccccc}
\hline & Beta & Std.Err. - of Beta & B & Std.Err. - of B & t & p-level \\
\hline ŽONG & 0.02 & 0.10 & 0.03 & 0.15 & 0.23 & 0.82 \\
KOMRE & 0.122 & 0.097 & 0.219 & 0.174 & 1.260 & 0.210 \\
KOOPRO & -0.199 & 0.097 & -1.110 & 0.538 & -2.062 & $\mathbf{0 . 0 4 2}$ \\
HEKS & -0.023 & 0.094 & -0.048 & 0.197 & -0.244 & 0.808 \\
\hline
\end{tabular}

Legenda: Beta - koeficijent parcijalne regresije; Std.Err. - of Beta - standardna greška koeficijenta parcijalne regresije; $t$-vrijednost testa Beta koeficijenata; p-level-značajnost Beta koeficijenta

U tabeli 3. vrijednost koeficijenta multiple korelacije između zavisne varijable Pogađanje vertikalnog cilja "čekićem" (ČEVER) i sistema varijabli specifičnih koordinativnih sposobnosti je $\mathbf{R}=\mathbf{0 . 3 7}$ što ukazuje na nešto slabiju povezanosti posmatranih sistema. Povezanost je $\mathrm{i}$ statistički značajna na nivou $\mathbf{p}=\mathbf{0 . 0 0 0}$ (Tabela $3 a$ ). Dobijena vrijednost $\mathbf{R}^{\mathbf{2}}=\mathbf{0 . 1 4 8 5}$ upućuje na zaključak da je 14.85\% ukupnog varijabiliteta rezultata pogađanja vertikalnog cilja ,čekićem“ (ČEVER) determinisano varijabilitetom sistema nezavisnih varijabli. Ostatak od $85.15 \%$ nije objašnjen regresionim modelom, dakle, pod uticajem je nekih drugih antropoloških karakteristika ili sposobnosti odbojkašica koje nisu predmet ovog istraživanja.

Tabela 3. Rezultati multiple regresione analize za zavisnu varijablu Pogađanje vertikalnog cilja „čekićem“ (ČEVER)

\begin{tabular}{ccccc}
\hline Model & Multiple R & Multiple R & Adjusted R & Std.Err. of Estimate \\
\hline $\mathbf{1}$ & 0.372196 & 0.148500 & 0.084814 & 1.736541 \\
\hline
\end{tabular}

Tabela 3a. Rezultati analize varijanse za zavisnu varijablu Pogađanje vertikalnog cilja „čekićem“(ČEVER)

\begin{tabular}{clccccc}
\hline \multicolumn{2}{c}{$\begin{array}{c}\text { ANOVA } \\
\text { (Effect) }\end{array}$} & SS & df & MS & F & Sig. \\
\hline \multirow{3}{*}{ ČEVER } & Regresson & 1433.77 & 2 & 358.44 & 7.743 & $\mathbf{0 . 0 0 0}$ \\
& Residual & 2314.66 & 37 & 46.29 & & \\
& Total & 3748.44 & 39 & & & \\
\hline
\end{tabular}


Pokazalo se također da se rezultati testa Pogađanje vertikalnog cilja „,̌ckićem“ (ČEVER), koji je korišten za procjenu preciznosti, mogu statistički značajno predvidjeti $(\mathbf{p}=\mathbf{0 . 0 0 7} \mathbf{i}$ $\mathbf{p}=\mathbf{0 . 0 0 2}$ ), na osnovu rezultata testova Koordinacija uz mrežu (KOOMRE) i Koordinacija u prostoru (KOOPRO). To potvrđuju i vrijednosti Beta koeficijenta za navedene nezavisne varijable (Beta=0.284 i $\mathbf{B e t a}=\mathbf{0 . 2 9 3}$ ). Ostale varijable specifičnog koordinativnog prostora nemaju statističku značajnost (Tabela 3 b).

Tabela 3b. Beta koeficijenti - relativni uticaj ili važnost svake nezavisne promjenljive

\begin{tabular}{ccccccc}
\hline & Beta & Std.Err. - of Beta & B & Std.Err. - of B & t & p-level \\
\hline ŽONG & -0.046 & 0.106 & 0.023 & 0.052 & -0.432 & 0.671 \\
KOMRE & 0.284 & 0.104 & 0.065 & 0.024 & -2.735 & $\mathbf{0 . 0 0 7}$ \\
KOOPRO & 0.293 & 0.105 & 0.068 & 0.022 & -2.633 & $\mathbf{0 . 0 0 2}$ \\
HEKS & 0.013 & 0.105 & 0.000 & 0.002 & 0.098 & 0.922 \\
\hline
\end{tabular}

Tabela 4. Rezultati multiple regresione analize za zavisnu varijablu Pogađanje horizontalnog cilja „čekićem“ $\boldsymbol{u}$ poziciji 2 (ČEPOZ2)

\begin{tabular}{ccccc}
\hline Model & Multiple R & Multiple $\mathbf{R}^{\mathbf{2}}$ & Adjusted R $^{\mathbf{2}}$ & Std.Err. of Estimate \\
\hline $\mathbf{1}$ & 0.44061 & 0.20244 & 0.135576 & 11.045297 \\
\hline
\end{tabular}

U tabeli 4. vrijednost koeficijenta multiple korelacije između zavisne varijable Pogađanje horizontalnog cilja "čekićem" u poziciji 2 (ČEPOZ2) i sistema varijabli specifičnih koordinativnih sposobnosti je $\mathbf{R}=\mathbf{0 . 4 4}$ što ukazuje na značajnu povezanosti posmatranih sistema. Povezanost je i statistički značajna na nivou $\mathbf{p = 0 . 0 0 1}$ (Tabela 4a). Dobijena vrijednost $\mathbf{R}^{\mathbf{2}}=\mathbf{0 . 2 0 2 4}$ upućuje na zaključak da je 20.24\% ukupnog varijabiliteta rezultata Pogađanja horizontalnog cilja, ,čekićem“ u poziciji 2 (ČEPOZ2) determinisano varijabilitetom sistema nezavisnih varijabli. Ostatak od $79.76 \%$ nije objašnjen regresionim modelom, dakle, pod uticajem je nekih drugih antropoloških karakteristika ili sposobnosti mladih odbojkašica. 
Tabela 4a. Rezultati analize varijanse za zavisnu varijablu Pogađanje horizontalnog cilja „čekićem“ u poziciji 2 (ČEPOZ2)

\begin{tabular}{ccccccc}
\hline \multicolumn{2}{c}{$\begin{array}{c}\text { ANOVA } \\
\text { (Effect) }\end{array}$} & SS & df & MS & F & Sig. \\
\hline \multirow{3}{*}{ ĆEPOZ2 } & Regresson & 553.78 & 2 & 138.44 & 5.587 & $\mathbf{0 . 0 0 1}$ \\
& Residual & 1239.06 & 37 & 24.78 & & \\
& Total & 1792.84 & 39 & & & \\
\hline
\end{tabular}

Pregledom tabele 4b, pokazalo se da se rezultati testa Pogađanje horizontalnog cilja „с̌ekićem“ u poziciju 2 (ČEPOZ2), koji su korišteni za procjenu preciznosti, mogu statistički značajno predvidjeti $(\mathbf{p}=\mathbf{0 . 0 0 4}$ i $\mathbf{p}=\mathbf{0 . 0 3 1})$ na osnovu rezultata testova Jednoručno žongliranje loptom kroz obruč $(Z ̌ O N G)($ Beta= -0.410) i Koordinacija uz mrežu (KOOMRE) (Beta= 0.280), koji su se koristili za procjenu koordinacije. Ostale varijable specifičnog koordinativnog prostora nemaju statističku značajnost.

Tabela 4b: Beta koeficijenti - relativni uticaj ili važnost svake nezavisne promjenljive

\begin{tabular}{cccccccc}
\hline & Beta & Std.Err. - of Beta & B & Std.Err. - of B & t & p-level \\
\hline ŽONG & -0.410 & 0.159 & -0.504 & 0.538 & -3.143 & $\mathbf{0 . 0 0 4}$ \\
KOMRE & 0.280 & 0.164 & 0.368 & 0.455 & 2.257 & $\mathbf{0 . 0 3 1}$ \\
KOOPRO & -0.158 & 0.188 & 0.199 & 0.158 & 0.571 & 0.571 \\
HEKS & 0.254 & 0.169 & 0.294 & 0.176 & 1.743 & 0.091 \\
\hline
\end{tabular}

\section{DISKUSIJA}

Bazične motoričke sposobnosti kao osnova na koju se, kroz dugogodišnji proces odbojkaškog treninga, nadograđuju specifične motoričke sposobnosti su značajne za uspjeh, jer u velikoj mjeri determinišu kvalitet igre pojedinca. S tim u vezi, situaciono-motoričke sposobnosti koje predstavljaju kombinaciju motoričkih i funkcionalnih sposobnosti sa tehničko-taktičkim znanjima su preduslov za rješavanje situacija nastalih u igri. Dakle, priprema u oblasti motoričkih i funkcionalnih sposobnosti, tehničko-taktičkih znanja, psihičkih (konativni i kognitivni) faktora, ali i faktor sportske sreće su od izuzetne važnosti za uspjeh u sportu pa i u odbojci. Dijagnostifikovanje strukture koordinacije je započelo davnih 80-ih godina (Hošek, 1976, Hošek-Momirović, 1981), nastavilo se i traje do danas (Šimonek, 2006; Moriss, 2008; 
Bokan, 2009; Brodani i Šimonek, 2010; 2013; 2014; Gongey i Kerketta, 2016). Svako novo saznanje potvrđuje atribut kompleksne motoričke sposobnosti, te je iz tog razloga sigurno jedna od neizostavnih motorička sposobnosti koja se mora pronaći u svakoj jednačini specifikacije ${ }^{2}$ svakog sporta. Širinu i raznolikost koordinativnih sposobnosti dokazuju njene dalje podjele, pa se tako, u stručnoj i naučnoj litetraturi mogu pronaći i pojavni oblici poput brzinske koordinacije (sposobnost preciznog izvođenja željenog pokreta u kratkom vremenu), ritmičke koordinacije (sposobnost izvođenja željenog zadatka u kontinuiranom ili diskontinuiranom ritmu), brzo učenje motoričkih zadataka, prostorno-vremenska orjentacija (sposobnost kontrolisanja više objekata u prostoru i vremenu, potreba za tzv. ,perifernim“ vidom), te pravovremenost. Dakle, koordinacija je nesporno bitna motorička sposobnost koja učestvuje u svakoj kretnoj manifestaciji pa tako i u zadanim testovima, no dobijeni rezultati zahtjevaju odgovor na pitanje: koji su to latentni faktori zapravo odredili koordinacione sposobnosti odbojkašica u istraživanju i na taj način preuzeli primat $\mathrm{u}$ realizaciji postavljenih zadataka?

Ono što se može na osnovu rezultata primijetiti je činjenica da postoji značajna statistička predikcija izvođenja motoričkih testova na osnovu specifične koordinacije. Do gotovo istih zaključaka došli su i autori ranijih istraživanja (Šabotić, 2004; Tahiraj, 2007; Babin, Bavčević i Vlahović, 2013; Schaal, Ransdell, Simonson i Gao, 2013; Stojanović i sar. 2014). Međutim, osim činjenice da koordinacija ima visok koeficijent urođenosti $\left(\mathrm{h}^{2}=0.80\right)$ (Pistotnik, 2003) i utvrđenog uticaja na izvođenje, pažnju privlači to da je ono, u većem procentu, zaista određeno nekim drugim neidentifikovanim (latentnim) faktorima ili sposobnostima odbojkašica. U prvom redu izražene su dvije sposobnosti unutar koordinacije koje su se već velikim dijelom osamostalile, a to su agilnost i ravnoteža čiju su interakciju potvrdili Ortega, Ruiz, Castillo i Sjostrom (2008) i Pradhan (2016). Osim agilnosti i ravnoteže, rezultati ovog istraživanja su pokazali da na koordinaciju odbojkašica indirektno utiču i snaga, brzina, izdržljivost,

\footnotetext{
${ }^{2}$ Višedimenzionalnost od koje zavisi uspjeh u igri, hipotetski je moguće zapisati u obliku linearne jednačine (Elsner, 1990): U= Ak1+Mk2+Fk3+Mik4+Ik5+Kk6+Sk7+Zsk8+Zfk9+PTk10+... Ekn. (U-uspjeh u odbojkaškoj igri, K1, k2 ,..., kn-koeficijent uticaja pripadajućih faktora (ponderi), A-antropometrijske karakteristike odbojkaša, Mmotoričke sposobnosti odbojkaša, F-funkcionalne sposobnosti odbojkaša, Mi-motorička znanja odbojkaša, Iintelektualne (kognitivne) sposobnosti odbojkaša, K-konativne osobine odbojkaša, S-socijalne karakteristike odojkaša, Zs-zdravstveni status odbojkaša, Zf-utjecaj vanjskih faktora (na takmičenju), PT-uslovi provođenja trenažnog procesa, E-greška (error)). Faktori uspješnosti u sportu definisani su hijerarhijski, što znači da na početku niza stoje najvažniji faktori ili dimenzije, a na kraju oni koji su manje važni. Tako definisana hijerarhijska struktura faktora naziva se jednadžba specifikacije u sportu. Ona je hipotetska ako se do hijerarhijske strukture faktora uspješnosti došlo na osnovu subjektivne procjene njihove važnosti (Milanović, 2013). hypothetical if to the hierarchical structure of the factors of success has been based on the subjective assessment of their importance (Milanovic, 2013).
} 
fleksibilnost, te sposobnost brzog reagovanja kao njeni integralni dijelovi, što se dokazalo kao tačno i u istraživanjima Kansala (2008), Lidiora i Ziva (2010) i Gangeya i Kerkette (2016) istraživajući, između ostalog, faktore uspješnosti u odbojci. Značajna karakteristika motoričkih testova ovog istraživanja je ta što su svi testovi podrazumijevali vještinu manipulacije određenim predmetom/rekvizitom. Konkretno, ovdje se radi o lopti. Na tu vrstu spretnosti utiču: osjećaj za oblik predmeta, osjećaj za njenu veličinu i težinu, elastičnost i inerciju (Poljšak, 1980). Sljedeći faktor o kojem se mora voditi računa je funkcionalne prirode, a odnosi se na pokretljivost zglobova, jačanje mišića pregibača prstiju i šake, podlaktica prilikom odigravanja lopte i jačanje mišića opružača pri dodavanju lopte. Lopta traži pokret, dinamiku, spretnost, okretnost, preciznost, brzinu i snalažljivost, a ponekad i snagu (Poljšak, 1980). Sve su ovo faktori, latentnog karaktera, kojima se mogu opravdati visoki procenti ukupnog varijabiliteta rezultata za sva tri testa iz sistema zavisnih varijabli. Zatim, treba imati na umu da se jedna situacija u igri nikada ne ponovi dva puta na isti način, tako da su odbojkašice primorane da reaguju u vrlo kratkom vremenu, bez obzira na to da li se nalaze u fazi napada ili u fazi odbrane. Iz toga se kao značajni faktori u realizaciji testova nameću istovremeno kretanje lopte i tijela (sinhronizacija), kontrola željenog pravca, kretanja lopte i tijela, te potreba za izvrsnom vizualnom percepcijom (Iveković, 2013). Možda najjasniji odgovor na pitanje uticaja latentnih faktora na izvođenje zadataka i njihovu sinergiju sa manifestnim sposobnostima (odbojkašica), dao je R. V. Roussev $(1998)^{3}$, koji je osmislio sistem koordinativnih sposobnosti sportiste i klasifikovao ga u pet nivoa:

Prikaz 1. Sistem koordinativnih sposobnosti sportiste (R. V. Roussev, 1998).

\begin{tabular}{|c|c|c|c|c|}
\hline \multicolumn{5}{|c|}{ Sistem koordinativnih sposobnosti sportiste } \\
\hline $\begin{array}{c}\text { NIVO } 1 \\
\text { Sposobnost regul. } \\
\text { ponašanja miš. vl. }\end{array}$ & $\begin{array}{c}\text { NIVO 2 } \\
\text { Sposobnost } \\
\text { regulacije mišićnog } \\
\text { naprezanja }\end{array}$ & $\begin{array}{c}\text { NIVO 3 } \\
\text { Sposobnost } \\
\text { regulacije kretanja } \\
\text { dijelova tijela }\end{array}$ & $\begin{array}{c}\text { NIVO } 4 \\
\text { Sposobnost kretanja } \\
\text { cijelog tijela }\end{array}$ & $\begin{array}{c}\text { NIVO } 5 \\
\text { Sposobnost regulisanja } \\
\text { pokretnih objekata }\end{array}$ \\
\hline $\begin{array}{l}\text { Regulacija izometrije } \\
\text { mišićnih vlakana }\end{array}$ & $\begin{array}{c}\text { Regulacija mišićne } \\
\text { izotonije }\end{array}$ & $\begin{array}{l}\text { Regulacija položaja } \\
\text { tokom kontakta }\end{array}$ & $\begin{array}{l}\text { Regulacija tjelesne } \\
\text { ravnoteže }\end{array}$ & $\begin{array}{c}\text { Regulacija manuelne } \\
\text { stabilizacije }\end{array}$ \\
\hline $\begin{array}{l}\text { Regulacija naprezanja } \\
\text { mišićnih vlakana }\end{array}$ & $\begin{array}{c}\text { Regulacija mišićne } \\
\text { auksotonije }\end{array}$ & $\begin{array}{c}\text { Kinestetička motorna } \\
\text { regulacija }\end{array}$ & $\begin{array}{c}\text { Regulacija rotacije } \\
\text { tijela }\end{array}$ & $\begin{array}{l}\text { Taktilna regulacija } \\
\text { manipulacije }\end{array}$ \\
\hline & & $\begin{array}{l}\text { Vremenska motorna } \\
\text { regulacija }\end{array}$ & $\begin{array}{l}\text { Vizuelna regulacija } \\
\text { lokomocije }\end{array}$ & $\begin{array}{l}\text { Vizuelna regulacija } \\
\text { manipulacije }\end{array}$ \\
\hline \multicolumn{5}{|c|}{$\begin{array}{l}\text { Regulacija motorne } \\
\text { imitacije }\end{array}$} \\
\hline & & $\begin{array}{l}\text { Akustična motorna } \\
\text { regulacija }\end{array}$ & & \\
\hline
\end{tabular}

\footnotetext{
${ }^{3}$ Preuzeto: Ragulj, N. (2004). Kineziologija znanost o pokretu. [PTT].www. marul.ffst.hr/ nrogulj/predavanje.
} 


\section{ZAKLJUČAK}

Mlade odbojkašice pokazale su da su njihove koordinativne sposobnosti u prostoru pri izvođenju zadatka pogađanje horizontalnog cilja ,čekićem“ (ČEHOR) statistički značajne. U testu pogađanje vertikalnog cilja „čekićem“ (ČEVER) kao značajne pokazale su se dvije vrste koordinacije, koordonacija u prostoru i koordinacija na mreži, dok su se u trećem testu pogađanje horizontalnog cilja „čekićem“ u poziciji 2 (ČEPOZ2), kao značajne pokazale koordinacija na mreži i jednoručno žongliranje loptom kroz obruč (ŽONG). S obzirom na to da je značaj i složenost koordinacije u ovom i sličnim transverzalnim istraživanjima evidentan, prvi zaključak je da latentni faktori, koji su odredili koordinacione sposobnosti odbojkašica, mogu djelovati i samostalno, ali i zavisiti jedan od drugog.

Vjerujemo da će se složiti mnogi da odbojkaška tehnika, u tom smislu, zahtijeva specifičnu koordinaciju. Jer veliki broj tehničko-taktičkih elemenata koji se primjenjuju u igri i velika varijabilnost korištenja istih, odbojku svrstava u red sportova za koje je specifična koordinacija neophodna. Ovakvu formulaciju specifične koordinacije definisao je između ostalih i Bompa (1985; 1999). Situaciona koordinacija je još složenija od specifične i nadograđuje se na nju. Ona bi se mogla opisati kao sposobnost uspješnog, nepredvidivog i svrsishodnog motoričkog reagiranja u "konfliktnim" takmičarskim situacijama (Metikoš, Milanović, Prot, Jukić i Marković, 2003).

Dakle, radilo se o opštoj, specifičnoj ili situacionoj koordinaciji, u istraživanju je došla do izražaja suština ove sposobnosti: pravilan odnos utvrđenih latentnih faktora kao dijelova cjeline, koji daju efektivne rezultate. Ukoliko se tome dodaju preduslovi kao: uska povezanost sa odbojkaškom tehnikom, zatim mogućnost rješavanja kompleksnih, nepredvidivih motoričkih zadataka (inteligencija), sticanje kinestetičkog osećaja, dobra procjena prostornih parametara, (sistematski trening), stečeno motoričko znanje (motoričko iskustvo), te nivo razvijenosti drugih motoričkih sposobnosti (brzine, snage, izdržljivosti, fleksibilnosti i sl.), drugi zaključak je da je koordinacija važna motorička sposobnost i da se bez nje ne može očekivati efikasno izvođenje zadanih tehničko-taktičkih struktura u odbojci.

Odbojka je jedna od najdinamičnijih sportskih igara sa stalnim mijenjanjem tipičnih i atipičnih situacija, koje igrač mora brzo uočiti, analizirati i na njih adekvatno reagirati. S tim u vezi, u trenažnom procesu treba težiti što većoj saglasnosti svih motoričkih sposobnosti neophodnih za uspjeh u odbojci. Viši nivo vladanja tehničko-taktičkim elementima, zahtijeva i viši nivo 
motoričke pripremljenosti. Samo takva priprema doprinosi boljoj, lakšoj i ekonomičnijoj primjeni složenih pokreta u takmičarskim uslovima. Da bi se postiglo efikasnije izvođenje tehničkih aktivnosti igrača odbojkaša potrebno je optimalno motoričko dostignuće, odnosno, određene "zalihe" stečenih motoričkih navika. Što su "zalihe" stečenih motoričkih navika, prije svega opšte koordinacije veće, time će se lakše ovladavati novim pokretima i nivo razvoja specifične koordinacije biti će veći (Marinković, 2011). Sve to nas navodi na treći važan zaključak ovog istraživanja: koordinacija, nesumnjivo, mora imati svoju svrhu. Mora biti funkcionalna, odnosno, treba se ispoljavati u cilju efikasne realizacija postavljenih zadataka.

\section{LITERATURA}

Babin, B., Bavčević, T. \& Vlahović, L. (2013). Relations of Motor Abilities and Motor Skills in 11 Year old Pupils. Croatian Journal of Education. 15(2), 251-274.

Bokan, M. (2009). Motoričke sposobnosti odbojkaša i testovi za njihovu procjenu. Fizička kultura, Beograd, 63(1), 116-125.

Bompa, T. O. (1985). Talent identification. Science Periodical on Research andTechnology in Sport, February, 1-11.

Bompa, T. O. (1999). Periodization. Theory and methodology of training (4th ed.). Champaign, (IL): Human Kinetics.

Brodani, J. \& Šimonek, J. (2010). Structure of Coordination Capacities and Prediction of Overall Coordination Performance in Selected Sports. Oradea (HUN): Editura Universitatii din Oradea.

Button, C., Wheat, J. \& Lamb, P. (2014). Why coordination dynamics is relevant for studying sport performance. In K. Davids, R. Hristovski, D. Araújo, N. B. Serre, C. Button, \& P. Passos (Eds.), Complex Systems in Sport (pp. 44-62). New York (USA): Routledge. Company.

PMid:25277366

Drabik, J. (1996). Children and Sports Training. Island Point, (VT): Stadion Publishing.

PMid:8699052

Elsner, B. (1990). Nogomet. Ljubljana (RS): Fakultet za telesno kulturo.

Gangey, O. \& Kerketta. I. (2016). Relationship between selected motor fitness and playing ability of volleyball players. International Journal of Academic Research and Development. ISSN: 24554197, Impact Factor: RJIF 5.22; 25-26. Rohini, Delhi, India.

Hošek, A. (1976.) Struktura koordinacije. Kineziologija, 6, 1-2.

Hošek, A. (1981). Povezanost morfoloških taksona s manifestnim i latentnim dimenzijama koordinacije. Kineziologija, 11(4).

Idrizović, K. (2011). Što je to koordinacija? U: Jukić I., Gregov C., Šalaj S., Milanović L., i sur. ur. Trening koordinacije, (pp. 28-41). Zagreb (RH): Kineziološki fakultet. Sveučilište u Zagrebu,

Iveković, I. (2013). Utjecaj motoričkog planiranja, koordinacije i sukcesivnih sposobnosti na motorièki razvoj i društveno ponašanje djece s teškoćama u razvoju. Hrvat. Športskomedicinski Vjesnik. 28, 99-107.

Kansal, D.K. (2008). Applied Measurements Evaluation and Sports selection. SSS Publication New Delhi.

Karalić, T. (2010). Preciznost kao faktor uspješnosti u tehničko-taktičkim strukturama odbojke (Precision as a factor of success in technical and tactical structures of volleyball). Unpublished doctoral dissertation. Istočno Sarajevo: Faculty of Physical Education and Sport. 
Karamatić, L. P., Vuljanić, A. \& Peršun, J. (2011). Razvoj koordinacije kod djeteta sportaša. U: Jukić I., Gregov C., Šalaj S., Milanović L. i sur. ur. Trening koordinacije (pp 470-3), Zagreb, (RH): Kineziološki fakultet Sveuèilišta u Zagrebu.

Lidor, R. \& Ziv, G. (2010). Physical and physiological attribute of female volleyball players: A review. Journal of Strength and Conditioning Research. 24(7), 1963-1973.

https://doi.org/10.1519/JSC.0b013e3181ddf835

PMid:20543736

Macner, I. (2011). Koordinacija kao preduvjet razvoju kondicijskih sposobnosti te usvajanju sportskih tehnika. U: Jukiæ I., Gregov C., Šalaj S., Milanović L., i sur. ur. Trening koordinacije, (pp 297300), Zagreb, (RH): Kineziološki fakultet Sveuèilišta u Zagrebu.

Marelić, N., Đurković, T. \& Rešetar, T. (2007). Dijagnostika kondicijskih sposobnosti mlađih dobnih kategorija u odbojci. Godišnja međunarodna konferencija Kondicijska priprema sportaša, (pp 277282), Zagreb, (RH): Kineziološki fakultet.

Marinković, D. (2011). Trening koordinacije u košarci. Kondicijska priprema sportaša 2011 - Trening koordinacije. Kineziološli fakultet Sveučilišta u Zagrebu, Udruga kondicijskih trenera Hrvatske. Zagreb.

Metikoš, D., Milanović, D., Prot, F., Jukić, I. \& Marković, G. (2003). Teorethical and metodical basics of coordination development. In D. Milanović, I. Jukić (Eds.). Strength and conditioning preparation in sport. Proceedings book of International scientific conference. (pp. 264-270). Zagreb, (RH): Faculty of Kinology Univerity of Zagreb. Sport assosiation of Zagreb.

Milanović, D. (2013). Teorija treninga. Zagreb (RH): Kineziološki fakultet Sveučilišta u Zagrebu.

Milanović, D., Šalaj, S. \& Gregov, C. (2012). Opća kondicijska priprema u funkciji zaštite zdravlja sportaša. Arhiv za higijenu rada i toksikologiju, 63, Suppl. 3, 103-119.

Morris, S. B. (2008). Estimating effect sizes from pretest-posttest-control group designs. Organizational Research Methods, 11(2), 364-386. https://doi.org/10.1177/1094428106291059

Njaradi, N. (2011). Koordinacija - obilježje pobjednika. U: Jukić I., Gregov C., Šalaj S., Milanović L., i sur. ur. Trening koordinacije, (pp 83-87), Zagreb (RH): Kineziološki fakultet Sveušilišta u Zagrebu.

Ortega, F.B., Ruiz, J.R., Castillo, M.J. \& Sjostrom, M. (2008). Physical fitness in childhood and adolescence: A powerful marker of health. International Journal of Obesity. 32(1):1-11.

https://doi.org/10.1038/sj.ijo.0803774

PMid:18043605

Pion, J., Fransen, J., Deprez, D., Segers V., Vaeyens, R., Philippaerts, R. \& Lenoir, M. (2015). Stature and Jumping Height Are Required in Female Volleyball, but Motor Coordination Is a Key Factor for Future Elite Success. Journal of Strength \& Conditioning Research; Volume 29- Issue 6 -p 1480-1485. https://doi.org/10.1519/jsc.0000000000000778

Pistotnik, B. (2003). Osnove gibanja: gibalne sposobnosti in osnovna sredstva za njihov razvoj v športni praksi. Ljubljana (RH): Fakulteta za šport, Inštitut za šport.

Poljšak, S. L. (1980). Od loptice do pušbola: vežbe i igre loptama u slici i reči. Beograd, (RS).

Pradhan, K. (2016). Performance indicators of inter university volleyball players in terms of their playing positions. Scientific Culture in Physical Education \& Sports, Twentyfirst Century Publications, Patiala. 651-656.

Schaal, M., Ransdell, L. B., Simonson, S. R., \& Gao, Y. (2013). Physiologic performance test differences in female volleyball athletes by competition level and player position. Journal of Strength and Conditioning Research, 27(7), 1841-1850. https://doi.org/10.1519/JSC.0b013e31827361c4

Stein, T., Simonidis, C., Seemann, W. \& Schwameder, H. (2010). A computational model of human movement coordination. Ed.: R. Dillmann. Advances in Artificial Intelligence. Proceedings of the 33rd Annual German Conference on AI, Karlsruhe, (pp 23-32), Berlin, (D): Springer. https://doi.org/10.1007/978-3-642-16111-7_2 
Stojanović, N., Stojanović, T., Stojanović, D., Herodek, K. \& Jurko, D. (2014). Uticaj koordinacionih sposobnosti na preciznost dodavanja lopte "čekićem" u odbojci. Defendologija, 35, 73-81. https://doi.org/10.7251/defsr1401003s

Strahonja, A. \& Janković, V. (1988). Metrijske karakteristike testova za procjenu faktora preciznosti ciljanjem. (Metrical characteristics of tests for the assessment of targeting precision factors). Kineziologija, 20 (1).

Strahonja, A., Janković, V. \& Šnajder, V. (1982). Analiza pouzdanosti i faktorske valjanosti situacionomotoričkih testova $\mathrm{u}$ odbojci. (Analysis of the reliability and factorial validity of situational-motoric tests in volleyball). Kineziologija, 14(5), 161-175.

Šabotić, B. (2004). Relacije nekih antropoloških karakteristika sa situaciono-motoričkim sposobnostima u sportskim igrama kod učenika prvog razreda srednjih škola. Niš (RS): Fakultet fizičke kulture, doktorska disertacija.

Šimonek, J. (1998). Hodnotenie a rozvoj koordinačných schopností 10-17 ročných chlapcov a dievčat [The assessment and development of coordination abilities of 10-17 years old boys and girls]. Nitra (SL): Univerzita Konštantína Filozofa v Nitre.

Simonek, J. (2006). Model of development of coordination abilities in the long-term sport preparation in volleyball. Oradea, (HUN): Editura Universitaii din Oradea.

Šimonek, J. (2009). Model rozvoja koordinačných schopnostív dlhodobej športovej príprav v športových hrách. Bratislava (SL): PEEM.

Šimonek, J. (2014). Coordination abilities in Volleyball. Warszaw/Berlin: DeGruyter. ISBN 978-837656-083-0; https://doi.org/10.2478/9783110370317

Šimonek, J. (2016). The effect of intervention on the changes of coordination factors in the youth sports preparation. Sport Science 9(2), 77-81.

Tahiraj, E. (2007). Antropometriske i motoričke karakteristike vrhunskih odbojkaša u svetu. Magistarski rad, Pristina, (SR).

Tomljanović M., Krespi, M. \& Bešlija, T. (2011). Integralni trening koordinacije u rukometu. U: Jukić I., Gregov C., Šalaj S., Milanović L., i sur. ur. Trening koordinacije, (pp1366-136), Zagreb, (RH): Kineziološki fakultet Sveučilišta u Zagrebu.

Urgesi, C., Savonitto, M.M., Fabbro, F. i Aglioti, S.M. (2012). Long- and short-term plastic modeling of action prediction abilities in volleyball. Psychol Res. 76, 542-560.

https://doi.org/10.1007/s00426-011-0383-y

PMid:22045443

Verstegen, M. \& Marcello, B. (2001). Agility and Coordination. In: High Performance Sports Conditioning. B. Foran, ed. Champaign: Human Kinetics.

PMCid:PMC113934

Vučetić, V., Sukreški M., Zuber, D. \& Sporiš, G. (2011). Dijagnostički postupci za procjenu razine koordinacije sportaša. U: Jukić I., Gregov C., Šalaj S., Milanović L., i sur. ur. Trening koordinacije, (pp42-49), Zagreb (RH), Kineziološki fakultet Sveučilišta u Zagrebu.

Yasumitsu, T. \& Nogawa, H. (2013). Effects of a Shor-Term Coordination Exercise Program During School Recess: Agility of Seven to Eight Year Old Elementary school children. Perceptual \& Motor Skills, 116(2), 598-610.

https://doi.org/10.2466/25.10.PMS.116.2.598-610

PMid:24032333 
Primljeno: 06.06.2017. Odobreno: 25.06.2017.

Korespodencija:

Prof. dr Tamara Karalić

Univerzitet u Banjoj Luci

Fakultet fizičkog vaspitanja i sporta

Katedra sportskih igara

Bulevar vojvode Petra Bojovića Ia

78000 Banja Luka, Republika Srpska/BiH

Tel: +38766 541309

E-mail: tamara.karalic@ffus.unibl.org 